\title{
CYBERSPACE, INTERNET, DAN RUANG PUBLIK BARU: AKTIVISME ONLINE POLITIK KELAS MENENGAH INDONESIA
}

Oleh:

\author{
Wasisto Raharjo Jati
}

\begin{abstract}
Abstrak
Artikel ini bertujuan untuk menganalisis mengenai cyberspace sebagai ruang publik baru bagi kelas menengah Indonesia. Konsep lama ruang publik berasal dari Habermas yang menilai ruang tersebut merupakan bagian dari proses komunikasi dan advokasi publik. Ruang tersebut dipahami sebagai ruang inklusif, deliberatif, dan juga partisipatif yang mendorong publik untuk berdiskusi satu sama lain. Kemunculan cyberspace melalui sosial media ini menarik untuk dicermati karena mampu mentransformasi ruang publik dalam bentuk digital. Dibandingkan dengan ruang publik, cyberspace mampu menarik perhatian bagi setiap segmen publik untuk komunikasi dan berinteraksi kapanpun dan dimanapun. Dari situlah kemudian proses kesadaran politik kelas menengah kemudian tercipta. Artikel ini akan mengelaborasi lebih lanjut mengenai aktivisme politik online di Indonesia.
\end{abstract}

\begin{abstract}
Article aims to analyze cyberspace as new public sphere among Indonesian middle class. Previous public sphere concet came from Habermas who argued sphere is a manifestation of public communication and advocacy process. This sphere is understood in favour of inclusice, deliberative, and participatory sphere which endorsed public to discuss each other. The emergence of cyberspace through social media is interesting to discuss, especially in order to analyze the transformation of public sphere in digital form. Compared with pybluc sphere, cyberspace is able to attract mass attention for communicating and participating in everytime and everywhere resulted in political awareness. This article seeks to elaborate more deeply on the case of online activism among Indonesian middle class.
\end{abstract}

Keywords: Online Activism, Indonesian Middle Class, Political Awareness. 


\section{A. Pendahuluan}

Perbincangan mengenai politik digital merupakan kajian baru dalam khazanah ilmu sosial dan ilmu politik di Indonesia. Pada umumnya diskusi mengenai hal-hal digital lebih dikaitkan dengan masalah teknologi dan informasi sehingga lebih bernuansa lebih teknis dan numerik. Meskipun demikian, titik tolak dari tulisan ini sebenarnya bermula dari dampak perkembangan teknologi yang sedemikian masif di kalangan masyarakat. Teknologi berperan besar dalam menyempitkan waktu, ruang, dan jarak sehingga saling terkoneksi satu sama lainnya dalam satu ruang bernama ruang siber (cyberspace). Dalam ruang tersebut, semua orang lintas benua dan lintas negara kemudian bisa saling berdiskusi dan berinteraksi satu sama lainnya. Dengan kata lain, keberadaan internet telah banyak membantu adanya proses pendalaman demokrasi (democracy deepening) dalam masyarakat sehingga masyarakat mampu tampil sebagai demos seutuhnya.

Penetrasi internet melalui cyberspace telah menyemai adanya deliberasi nilai-nilai demokrasi seperti halnya kesukarelaan (voluntarism), kesamaan (egalitarian), maupun juga praktik berjejaring (networking) menyebar dan diterima secara meluas dalam masyarakat. Masyarakat pun dengan mudah dan cepat dapat membentuk peer group berdasarkan kesamaan minat maupun isu spesifik tertentu. Selain itu pula, suara minoritas yang selama ini termarjinalkan dalam praktik majoritarian pada sistem demokrasi kovensional, mendapatkan tempat untuk mengartikulasikan kepentingan dan identitasnya. Adanya ruang yang dinamis dan heterogen itulah yang membuat publik ramai menjadi netizen secara aktif maupun pasif dalam cyberspace. Berbagai macam isu dan tema yang diperbincangkan dari berbagai sumber memicu adanya kesadaran kritis publik dalam menilai dan memandang suatu peristiwa tertentu. Implikasinya yang ditimbulkan kemudian adalah munculnya para kelas menengah terdidik yang melek secara politik.

Terdapat dua tujuan penting dalam relasi antara cyberspace dengan demokrasi yakni 1) aktivisme dan 2) preservasi. Makna aktivisme merujuk pada pengertian pada terbentuknya gerakan politik sedangkan makna preservasi yakni lebih dilihat bahwa cyberspace sebagai ruang demokrasi.

Tulisan ini akan menampilkan sisi aktivisme dalam kasus cyberspace dalam kasus kelas menengah Indonesia. Trend aktivisme digital memang menghangat seiring dengan munculnya berbagai macam gerakan politik semisalnya saja Zapatista, Occupy, N20 Seattle, Arab Springs, maupun juga kasus Relawan dalam Pemilu Presiden Indonesia tahun 2014 silam. Pembahasan tulisan ini secara lebih lanjut akan mengupas 1) analisis terhadap krisis ruang publik dan saluran representasi politik dalam situasi politik kekinian, 2) munculnya cyberspace sebagai ruang publik baru dalam kelas menengah Indonesia, 3) analisis terhadap studi kasus aktivisme online yang berkembang dalam kasus kelas menengah Indonesia dan 3) kesimpulan dari pemaparan mengenai cyberspace tersebut.

\section{B. Krisis Ruang Publik dan Saluran Representasi Kepentingan}

Pengertian ruang publik menurut Habermas terkesan masih utopis dan optimis karena mengandaikan bahwa ruang publik iu adalah arena inklusif dan pluralis bagi setiap orang untuk bisa berpartisipasi dalam arena tersebut. Rasionalitas memang menjadi kunci 
mendasar dari implikasinya hadirnya ruang publik dalam masyarakat yang kemudian menciptakan adanya masyarakat kritis dan independen. Namun yang menjadi pertanyaan dari konsep ruang publik ini kemudian dibentuk dan diaktualisasikan dalam ruang msyarakat. Adapun penjelasan dari Habermas mengenai prakondisi terbentuknya ruang publik ini dapat dijelaskan sebagai berikut ini 1) Seberapa kuat kekuatan pasar yang menjadi fondasi berdirinya ruang publik. Hal ini terkait dengan nilai-nilai liberalisme individu yang diusung dalam masyarakat borjuasi. Ruang publik sendiri tumbuh dari proses transisi dari kapitalisme liberal menjadi kapitalisme terorganisir (Calhoun, 1992:6), dimana saat itulah kebutuhan ruang publik menjadi meningkat bagi publik dalam dinamika kehidupan yang mekanis dan merkantilis. Oleh karena itulah demokrasi dipiluh sebagai jalan untuk memastikan bahwa ekspresi kebebasan maupun individu mendapatkan perlindungan hukum. 2) seberapa independen ruang publik tersebut bebas dari intervensi politik yang dilakukan oleh negara maupun pasar. Hal ini penting mengingat transisi dari government menuju governance sendiri membutuhan adanya derajat independensi antara aktor negara, pasar, maupun masyarakat sipil. Posisi ruang publik ini menarik dikarenakan berada di antara (in-between) antar ketiga aktor tersebut yang memungkinkan masing-masing aktor tersebut saling beradvokasi dan bernegosiasi satu sama lainnya.

Secara garis besar, ruang publik dideskripsikan dalam tiga ranah penting yakni 1) ruang publik sebagai arena. Makna tersebut mengindikasikan bahwa ruang publik menyediakan basis komunikasi antar masyarakat. 2) ruang publik itu adalah publik itu sendiri. Makna tersebut mengindikasikan bahwa publik adalah aktor penting dalam menjalankan demokrasi dari tingkatan akar rumput. 3) ruang publik adalah agen. Maksudnya ruang publik itu merupakan agen / alat penting dalam menyampaikan aspirasi dari akar rumpur menuju bawah (Schuler \& Day, 2004: 4-6).

Ketiga makna ruang publik tersebut berkaitan dengan pengalaman Barat dalam membangun demokrasi dengan komparasi kasus Jerman dan Prancis. Pola menarik yang bisa ditarik kedua kasus tersebut adalah terbentuknya jaringan korporatisme antar ketiga anggota tersebut sehingga terciptalah pola checks and balances antar ketiga ranah tersebut. Pada akhirnya kemudian, relasi antar ketiga ranah tersebut dalam ruang publik menghasilkan opini publik sebagai hasil kesepakatan dan partisipasi antar aktor dalam ruang publik (Habermas, 2015:2). Namun demikian, pembentukan opini publik dalam ruang publik tersebut juga perlu dilihat perukaran sumber daya masing-masing aktor. Dalam hal ini, ruang publik yang dikendalikan borjuasi (bourgeoises public sphere) menjadi penting untuk dibicarakan karena aktor inilah yang mendorong adanya diseminasi nilainilai demokrasi dalam ruang publik. Namun tanpa mengucilkan peran rakyat jelata (plebeian) sebagai motor demokrasi, kalangan borjuasi lebih siap dalam mendukung dan mengupayakan terbentuknya ruang publik tersebut dengan argumentasi bahwa semangat libertarian dan egalitarian lebih berada dalam aktor borjuasi.

Dengan kata lain, rasionalisasi menjadi kata kunci penting dalam membangun institusionalisasi ruang publik dalam demokrasi, yang tidak semata-mata diokupansi oleh beberapa kepentingan privat yang mengatasnamakan kepentingan publik. 
Dari sinilah kemudian rasionalitas dalam ruang publik dipertaruhkan antara yang willie (kehendak rasionalitas umum) dengan willkur (agregasi kepentingan khusus) (McCharty, 1992: 51). Dua hal itulah yang menjadi titik kritis dalam memahami ruang publik. Meskipun ruang publik dianggap sebagai ruang inklusif, egalitarian, dan dianggap sebagai fondasi penting dalam demokrasi, namun terdapat adanya segregasi (sectionalism) maupun juga kondisi yang memungkinan (condition of possibility) untuk memunculkan adanya ruang publik dalam masyarakat (Subijanto, 2014).

Adanya dua pertanyaan kritis mengenai ruang publik kemudian yang dipakai dalam memaknai munculnya cyberspace yang dihadirkan oleh perkembangan teknologi internet masa kini dalam menumbuhkembangan demokrasi dalam kontek masyarakat kekinian. Demokrasi modern kini sudah menuju model representasi (representation democracy) untuk menghadirkan dan mengartikulasikan kepentingan publik yang begitu luas agar direalisasikandalam bentuk kebijakan (absent but present), namun seringkali yang terjadi pada konteks sekarang ini, representasi demokrasi tidak berjalan maksimal karena posisi wakil rakyat yang menjadi saluran representasi publik antara ada dan tiada (being present and yet not present) (Soeseno, 2013: 29-30). Ketidakefektian representasi dalam menjalankan kontrolnya sebagai wakil dikarenakan derajat kebebasan yang dimiliki oleh wakil dimana dia mewakili suatu konstituen, namun belum tentu kinerjanya diawasi oleh konstituennya. Hal ini dikarenakan adanya berbagai kepentingan yang perlu dipenuhi oleh wakil tersebut. Kondisi tersebut belum ditambah dengan adanya elitisme dalam kekuasaan sehingga menciptakan adanya jebakan oligarkis dalam representasi. Pada akhirnya kemudian, ruang publik berikut pula representasi politik tidak berjalan efektif dan efisien dalam mengartikulasikan kepentingan publik untuk dieksekusi dalam kebijakan.

Ketika ruang publik sebagai fondasi berjalannya demokrasi secara prosedural tidak berjalan dengan baik. Maka kebutuhan untuk membentuk saluran representasi maupun ruang publik baru menjadi sangat urgen dan signifikan dalma masyarakat Indonesia. Oleh karena itulah manakala penetrasi internet sudah sedemikian masif dalam masyarakat, makan saat itulah kemudian intenet ditempatkan sebagai ruang publik dan slauran representasi baru publik.

\section{Munculnya Cyberspace sebagai Ruang Publik Kelas Menengah Indonesia}

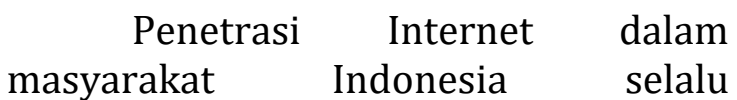
berkembang setiap tahunnya. Menurut data yang dhimpun dari APJII (2015: 9) menunjukkan bahwa sepanjang periode 2013-2014 terdapat 71,19 juta pengguna internet di Indonesia dengan mayoritas pengguna internet adalah kelas menengah urban sebesar 83,4 persen berbanding dengan pertumbuhan 6 persen di pedesaan. Adapun untuk angka penetrasi Internet di Indonesia juga mengalami kenaikan signifikan yang semula hanya 28 persen pada tahun 2013, kini tahun 2014 silam mencapai 34 persen. Maka diprediksi akan terjadi kenaikan pengguna internet dari kelas menengah pada tahun berikutnya mengingat semakin terintegrasi dan intens internet dalam pemenuhan kebutuhan sehari-hari.

Profil kelas menengah sebagai netizen aktif dalam pengguna internet di Indonesia sebagian besar didominasi 
kalangan pekerja (55 persen), mahasiswa (18 persen), dan juga ibu rumah tangga (16 persen) (APJII, 2015: 14). Pulau Jawa - Bali sendiri menenmpatkan sebagai populasi internet terbesar sebesar 52 persen diikuti Sumatera sebesar 18,6 persen, sisanya 13,4 persen terkonsentrasi di Indonesia Timur (APJII 2015: 26). Adapun aktivitas penggunaan internet bagi kelas menengah Indonesia didominasi kebutuhan leisure and pleasure seperti halnya sosialisasi (71 persen), informasi (65,3 persen), mengikuti perkembangan zaman 51,2 persen), dan bersenang-senang (32,6 persen) (APJII, 2015: 30). Dengan melihat adanya berbagai temuan tersebut, bisa diindikasikan bahwa hubungan ketergantungan kelas menengah Indonesia terhadap internet semakin meninggi.

Terhadap kemunculan internet sebagai ruang publik baru kelas menengah Indonesia, hal itu sebenarnya bisa dilihat dari intensitas penggunaan sosial media sebagai alat utama media baru di Indonesia. Adapun media sosial utama yang menjadi trendsetter di kalangan kelas menengah Indonesia seperti halnya WhatsApp (WA), Facebook, dan Twitter yang diakses melalui perangkat smartphone. Mayoritas kelas menengah sebagai netizen aktif maupun pasif dalam cyberspace mengakses media sosial melalui smarphone mencapai 85 persen berbanding dengan akses lewat laptop mencapai 32 persen. Prosentase intensitas frekuensi penggunaan media sosial tersebut seperti halnya Facebook (14 persen), WhatsApp (12 persen), maupun Twitter (11 persen) sehingga kemudian menempatkan Indonsia sebagai 'the social media capital of the world' (Jati, 2015).

Adanya temuan bahwa banyaknya fitur media sosial yang diakses oleh kelas menengah tersebut menujukkan adanya gejala overconnected (Yuswohady, 2013). Gejala tersebut menunjukkan adanya intensitas tinggi bagi kelas menengah Indonesia untuk saling berkomunikasi dan bersosialisasi satu sama lainnya berdasarkan kesamaan tema, isu, maupun kepentingan. Adanya komunikasi lewat sosial media yang saling berjejaring tersebut menghasilkan masyarakat berjejaring (network society). Pengertian masyarakat berjejaring tersebut terbentuknya ikatan kewarganegaraan online berdasarkan pada kesamaan minat isu dan topik. Perkembangan globalisasi mutakhir menempatkan bahwa saluran komunikasi, publik, maupun juga agen advokasi kebijakan tidak lagi berada dalam ranah lingkup nasional, namun juga merambah ranah internasional.

Berbagai pola menarik itulah yang ditemui dalam perbincangan kelas menengah Indonesia melalui media sosial adalah dapat membangun jejaring berdasarkan ikatan pertemanan yang kemudian berkembang dalam bentuk ikatan lainnya seperti ikatan ideologis, ikatan ketertarikan terhadap sesuatu, maupun peminatan isu tertentu, meskipun mereka tidak mengenal sebelumnya. Hal itu kemudian juga berimplikasi pada proses redefinisi terhadap konteks kewarganegaraan dalam ruang publik. Sebelumnya dalam teori klasik, ruang publik dibentuk berdasarkan kewarganegaraan yang berbasiskan pada tanah (ius soli) maupun juga darah (ius sanguinis). Namun adanya cyberspace sebagai ruang publik kemudian menciptakan adanya deteroterialisasi kewarganegaraan sehingga memunculkan basis kewarganegaraan internet (netizenship). Selain meniadakan adanya ius soli maupun ius sanguinis, pertanyaan penting yang 
dalam netizenship ini adalah konteks sense of belonging maupun juga konteks token of membership itu dijalankan. Logika ruang publik mengamanakan adanya konteks nation sebagai wadah tunggal terbentuknya ruang publik tersebut. Berbagai istilah yang muncul seperti Twitterland maupun Facebookland untuk menegasikan makna dan eksistensi nation tersebut, namun identitas seperti apakah yang ditampilkan cyberspace tersebut. Maka untuk menjawab pertanyaan tersebut, hal terpenting untuk menitikberatkan pada komparasi parameter-parameter antara konsepsi ruang publik lama Habermas dengan ruang publik sebagai cyberspace.

\section{Tabel 1 : Komparasi Ruang Publik dengan Cyberspace}

\begin{tabular}{|c|c|c|c|}
\hline No & $\begin{array}{l}\text { Paramater } \\
\text { Ruang } \\
\text { Publik } \\
\text { Habermas }\end{array}$ & $\begin{array}{l}\text { Ruang } \\
\text { Publik }\end{array}$ & Cyberspace \\
\hline 1 & $\begin{array}{l}\text { Aktor } \\
\text { Pendukung } \\
\text { Ruang } \\
\text { Publik }\end{array}$ & $\begin{array}{l}\text { Kelas } \\
\text { Borjuasi }\end{array}$ & Netizen \\
\hline 2 & $\begin{array}{l}\text { Kewarga- } \\
\text { negaraan }\end{array}$ & $\begin{array}{l}\text { Berbasiskan } \\
\text { pada } \\
\text { Identitas ius } \\
\text { sanguinis } \\
\text { dan ius soli }\end{array}$ & $\begin{array}{l}\text { Berbasiskan } \\
\text { pada } \\
\text { Kesamaan } \\
\text { Kepentingan } \\
\text { dan Isu }\end{array}$ \\
\hline 3 & $\begin{array}{l}\text { Bentuk } \\
\text { Ruang } \\
\text { Publik }\end{array}$ & $\begin{array}{l}\text { Fasilitas } \\
\text { Umum } \\
\text { seperti Kafe, } \\
\text { Restoran, } \\
\text { Kampus, dan } \\
\text { lain } \\
\text { sebagainya. }\end{array}$ & Sosial Media \\
\hline 4 & $\begin{array}{l}\text { Fungsi } \\
\text { Ruang } \\
\text { Publik }\end{array}$ & $\begin{array}{l}\text { Komunkasi } \\
\text { \& Advokasi }\end{array}$ & $\begin{array}{l}\text { Leisure and } \\
\text { Pleasure }\end{array}$ \\
\hline 5 & $\begin{array}{l}\text { Jangkauan } \\
\text { Ruang } \\
\text { Publik }\end{array}$ & $\begin{array}{l}\text { Dalam satu } \\
\text { negara }\end{array}$ & $\begin{array}{l}\text { Lintas } \\
\text { negara }\end{array}$ \\
\hline
\end{tabular}

Sumber: diolah dari berbagai sumber
Berdasarkan tabulasi tersebut, pergeseran dari ruang publik dalam lingkup konvensional menuju arena cyber telah menimbulkan berbagai macam konsekuensi logis. Salah satunya ruang dan waktu dalam komunikasi ruang publik. Adapun teorisasi lama mengenai ruang publik menitikberatkan pada pola terbentuknya jaringan inklusif yang terjalin antar anggota kelompok elemen borjuasi. Namun kini dengan munculnya cyberspace sendiri kemudian memunculkan adanya jejaring masyarakat sipil lintas negara. Ketiadaan teritorial dan identitas lainnya kemudian menjadikan nilai-nilai demokrasi substantif itu muncul dalam cyberspace seperti voluntarisme, egalitarian, maupun juga emanisipasi itu tumbuh

Maka, cyberspace sebagai ruang publik baru dalam kelas menengah Indonesia juga memberikan pengaruh besar dalam terbentuknya kesadaran politik publik. Berkat berbagai macam informasi yang disajikan dalam cyberspace tersebut kemudian menampilkan kelas menengah yang kritis dan politis terhadap perkembangan politik mutakhir. Meskipun kesadaran itu masih dalam berada arena leisure and pleasure dan masih melihat berbagai konstelasi politik tersebut dipandang sebagai everyday politics. Secara bertahap kesadaran politik itu sudah melembagakan diri dalam bentuk ikatan-ikatan korporatisme yang dijalin melalui cyberspace tersebut.

\section{Aktivisme Online dan Cyberspace Kelas Menengah Indonesia}

Tantangan dalam cyberspace kasus kelas menengah Indonesia kemudian adalah bagaimana menerjemahkan berbagai aktivisme cyber tersebut dalam contoh gerakan politik nyata dalam ruang publik. 
Persoalan tersebut merupakan aspek krusial dan penting, terlebih lagi untuk merubah kebiasaan leisure and pleasure dalam penggunaan media sosial tersebut agar menjadi lebih produktif. Kegiatan gerakan politik tersebut merupaka bentuk political exposure yang selama ini jarang dilakukan oleh kelas menengah Indonesia, terlebih kalau isu dan tema yang diangkat tidak menarik sama sekali. Namun sebelum membahas mengenai prospek gerakan online tersebut, terdapat masalah krusial dalam membincangkan internet dalam demokrasi Indonesia. Masalah pertama, internet itu sebaiknya bebas atau berada dalam domain negara. Persoalan tersebut sebenarnya merujuk pada penguasaan dan alokasi jariangan internet. Dalam kasus negara-negara berkembang terutama kawasan Asia Tenggara, persoalan tersebut merupakan persoalan penting mengingat perkembangan internet di kalangan kelas menengah yang masif, sehingga berupaya mendorong negara untuk melakukan kontrol dan sensor terhadap internet.

Dalam kasus Indonesia sendiri, kontestasi antara negara dengan masyarakat dalam internet sebagai ruang publik diperlihatkan dari adanya serangkaian regulasi yang berusaha untuk mengontrol internet seperti halnya UU Informasi dan Transaksi Elektronik (UU ITE) 2008 maupun juga kampanye "Internet Sehat dan Aman" dari Kementerian Komunikasi dan Informatika (Kominfo). Sementara masyarakat terutama kalangan netizen berusaha untuk resisten tersebut apalagi jika mencermati pasal-pasal dalam UU ITE tersebut kerap kali digunakan untuk menjerat para netizen dengan tuduhan phising, bullying, dan lain sebagainya, dimana yang utama sebenarnya lebih mengarahkan kepada pengawasan negara terhadap aktivitas internet dalam dunia maya. Masalah kedua, perlu adanya transformasi aktivitas internet bagi kelas menengah Indonesia sendiri untuk lebih produktif dalam menggunakan internet. Selama ini aktivitas leisure and pleasure emmang mendominasi terhadap aktivitas intenet publik, namun perlu sekiranya ada perubahan terhadap aktivtas tersebut sebaai aktivitas perubahan. Dinamika kelas menengah Indonesia kini menunjukka menuju arah gerakan perubahan sosial. Hal tersebut dari berbagai macam percakapan media sosial yang berusaha mempengaruhi dan mengajak anggota masyarakat lain untuk berpartisipasi dalam suatu event tertentu. Oleh karena itulah, sangat penting untuk menyimak perkembangan aktivitas online tersebut dalam lanskap Indonesia.

Aktivisme online merupakan bagian dari bentuk aktualisasi dari praktik politik digital dalam masyarakat. Adapun pengertian digital politik memiliki pengertian multiintepretatif, namun demikian kristalisasi dari berbagai macam konsep tersebut kemudian merujuk pada terbentuknya ruang publik dalam dunia maya (cyberspace) (Postill, 2012). Ruang tersebut adalah arena non struktural, dinamis, dan egaliter yang memungkinkan semua orang untuk berpartisipasi dan berpendapat melalui jejaring online. Perkembangan cyberspace di Indonesia memang lambat, namun menunjukkan trend positif dalam persebarannya. Membicarakan aktivitas online dalam kasus gerakan politik kelas menengah Indonesia perlu dilihat dalam beberapa tahapan seperti halnya kesadaran politik (political awareness), civic engangement (keterikatan sipil), maupun juga gerakan politik (political movement). Dalam setiap tahapan tersebut, gerakan politik yang ditampilkan oleh kelas menengah 
Indonesia memiliki karakter politik yang beragam satu sama lainnya.

Titik tolak dalam memahami dan membincangan aktivisme online di Indonesia sendiri sebenarnya berawal dari kemunculan UU ITE tahun 2008 yang disahkan oleh Pemerintah untuk mengatur informasi dan jasa elektronik berbasis online. Poin-poin krusial dalam UU ITE tersebut terletak pada pasal 27 ayat 1 dan 3, pasal 28 ayat 2 , dan pasal 31 ayat 3 yang seringkali digunakan aparat untuk menjebloskan netizen ke penjara. Adapun substansi per pasal tersebut jika digeneralisasikan adalah larangan untuk melakukan transmisi konten informasi yang berpotensi melakukan pencemaran nama baik, menyebar berita negatif, maupun juga menyebarkan isu yang sifantnya konfliktual. Setidaknya sejak hadirnya UU tersebut, terdapat lima korban UU ITE ini sejak tahun 2011-sekarang. Namun demikian, di luar lima nama korban lain sebenarnya masih banyak lagi korban dari UU ini. Hal itulah yang menjadi poin penting dalam menganalisis internet dan demokrasi di Indonesia.

Seperti yang telah diuraikan di awal, mayoritas pengguna media sosial di Indonesia didominasi kebutuhan leisure and pleasure seperti halnya komunikasi dan advokasi. Catatan penting yang perlu disimak dalam mengelaborasi kebutuhan leisure and pleasure tersebut terletak pada media sosial tersebut menyediakan relasi ruang publik intim yang mampu menarik perhatian sesama netizen. Mayoritas kelas menengah pengguna media sosial menggunakan internet sebagai sarana curhat baik itu sifatnya negatif maupun positif yanng kemudia ditanggapi dan dikomentari oleh netizen. Sejatinya, cyberspace yang berbasiskan media sosial ini mampu melakukan transformasi masalah privat menjadi ruang publik yang kemudian untuk dikritisi satu sama lainnya tergantung pada isu yang diangkat. Adanya platform media sosial yang real time menjadikan isu privat kemudian menjadi tersebar ke dalam ruang diskusi publik lainnya. Selain halnya menawarkan proses intim dan respons yang cepat, keunggulan ruang publik yang ditawarkan dalam cyberspace ini adalah mampu menarik dukungan massa yang kuat.

Teknologi mampu untuk menciptakan dan membangkitkan kohesivitas kelas menengah secara artifisial dan komunal. Hal itulah yang kerap kali berpotensi menciptakan adanya people power dari kelas menengah Indonesia karena hanya berdasarkan pada obrolan di mdia sosial. Adanya rasa afeksi maupun afiliasi terhadap isu yang dibentuk dalam media sosial menjadi motor penggerak bagi kelas menengah untuk berdemonstrasi. Kedua rasa itulah yang kemudian membentuk rasa kolegialitas untuk membentuk suatu gerakan komunal bersama.

Adapun isu-isu yang biasanya menjadi trendsetter dalam kelas menengah Indonesia masih berkutat pada masalah pelayanan publik, ketimpangan ekonomi, maupun elitisme kekuasaan. Ketiga masalah itulah yang menjadi obrolan di media sosial selain halnya masalah gaya hidup yang menjadi habitus kelas menengah kekinian. Kelas menengah yang condong pada gaya hidup sebenarnya merupakan kontinuitas dari fenomena orang kaya baru (OKB) yang hadir kembali di Indonesia paska pertumbuhan ekonomi sebesar 6-7 persen sepanjang 20082013. Media sosial justru digunakan sebagai sarana pemasaran dan ajang eksistensi diri. Mereka cenderung apolitis terhadap perkembangan politik kekinian, dan lebi meyukai pada hal-hal 
yang sifatnya hiburan daripada berita politik. Dengan demikian sebenarnya terdapat dua pola aktivisme kelas menengah yang bisa dibaca dalam kasus media sosial sebagai cyberspace,melalui tabulasi berikut ini.

Tabel 2: Komparasi Aktivisme Online Kelas Menengah Indonesia

\begin{tabular}{|l|l|l|l|}
\hline No & $\begin{array}{l}\text { Parameter } \\
\text { Aktivisme }\end{array}$ & $\begin{array}{l}\text { Kelas } \\
\text { Menengah } \\
\text { Politis }\end{array}$ & $\begin{array}{l}\text { Kelas } \\
\text { Menengah } \\
\text { Apolitis }\end{array}$ \\
\hline 1 & $\begin{array}{l}\text { Tema dan Isu } \\
\text { Pembentuk }\end{array}$ & $\begin{array}{l}\text { Isu-Isu Politis } \\
\text { dan Ekonomi }\end{array}$ & $\begin{array}{l}\text { Gaya Hidup \& } \\
\text { Hiburan }\end{array}$ \\
\hline 2 & $\begin{array}{l}\text { Orientasi } \\
\text { Gerakan }\end{array}$ & $\begin{array}{l}\text { Kelompok } \\
\text { Penekan } \\
\text { (pressure } \\
\text { groups) }\end{array}$ & $\begin{array}{l}\text { Kelompok } \\
\text { Kepentingan } \\
\text { (interest } \\
\text { groups) }\end{array}$ \\
\hline 3 & $\begin{array}{l}\text { Kebutuhan } \\
\text { Gembentuk }\end{array}$ & $\begin{array}{l}\text { Kebutuhan } \\
\text { akan prestasi } \\
\text { (need to } \\
\text { achievement) }\end{array}$ & $\begin{array}{l}\text { Kebutuhan } \\
\text { akan eksis } \\
\text { (need to exist) }\end{array}$ \\
\hline 4 & Sifat Gerakan & $\begin{array}{l}\text { Inklusif dan } \\
\text { Komunal }\end{array}$ & $\begin{array}{l}\text { Esklusif dan } \\
\text { Elitis }\end{array}$ \\
\hline 5 & $\begin{array}{l}\text { Relasi } \\
\text { dengan }\end{array}$ & $\begin{array}{l}\text { Oposisi- } \\
\text { Konstuktif }\end{array}$ & Dependen \\
\hline
\end{tabular}

Sumber: Diolah berbagai sumber data

Tabulasi tersebut mengindikasikan bahwa cyberspace berbasis media sosial telah menciptakan adanya digital devide dan juga digital sectionalism dalam kelas menengah Indonesia. Munculnya kelas menengah politis lahir dikarenakan adanya kesadaran politik yang dilahirkan dari proses sosialisasi dan komunikasi isu-isu kritis di media sosial. Sedangkan kelas menengah apolitis merupakan bagian dari proses kontinuitas, atau mungkin bisa dikatakan sebagai digitalisasi konsumsi yang didorong oleh sosial media. Konsumsi komoditas merupakan bentuk manifestasi identitas bagi kelompok yang kemudian menghasilkan segeregasi kelas menengah tersebut antara yang kelas menengah atas, kelas menengah-menengah, dan juga kelas menengah bawah. Dibandingkan dengan kelas menengah politis, dimensi lesiure and pleasure yang dimiliki oleh kelas menengah apolitis lebih tinggi. Mereka lebih menggunakan sosial media sebagai sarana untuk memperkuat konsolidasi dan eksklusifitas kelompok dibandingkan untuk membentuk gerakan politik. Seperti yang telah dijelaskan sebelumnya bahwa terdapat berbagai tahapan dalam menganalisis gerakan politik kelas menengah politis tersebut. Adapun analisis mengenai tahapan geraka kelas menengah politis disesuaikan dengan kasus gerakannya dapat dijelaskan sebagai berikut ini.

Pertama, kesadaran politik (political awareness) dalam kasus kelas menengah Indonesia sebenarnya bisa dilacak dari kasus Prita vs Omni yang mengemuka pada tahun 2009-2010. Kasus tersebut begitu meyita perhatian netizen, terlebih lagi karena alasan penangkapan Prita dikarenakan keluhan atas pelayanan medis rumah sakit yang buruk. Prita dijerat melalui Pasal 27 ayat 3 dalam UU ITE dengan tuduhan melakukan pencemaran nama baik. Kondisi diskriminasi yang dialami oleh Prita itulah yang kemudian mendorong netizen membentuk adnaya gerakan moral untuk melawan kesewenangwenangan tersebut. Adanya gerakan politik dengan tagar \#KoinCintaPrita tersebut mengindikasikan sosial media tampil sebagai pemantik gerakan yang cukup efektif dalam menarik atensi kelas menengah Indonesia. Semula gerakan \#KoinCintaPrita sendiri hanya bernuansa gerakan moral berkembang menjadi gerakan politik yang kemudian mampu untuk menekan proses peradilan bahwa Prita sendiri tidak bermasalah/ Hasilnya kemudian adanya PK (Peninjauan Kembali) oleh Mahkamah Agung pada September 2012 membebaskan Prita dari segela tuduhan. 
Berdasarkan kasus Prita tersebut menarik untuk dicermati, sosial media kemudian tumbuh dan berkembang sebagai alat penekan terhadap pemerintah yang lebih efektif dan efisien ketimbang melakukan demonstrasi di jalanan. Selain itu, sosial media juga mampu menggalang atensi publik untuk membentuk suatu gerakan. Oleh karena itulah gerakan dengan tagar \#KoinCintaPrita tersebut menandai adanya gerakan aktivisme online baru dalam lanskap politik Indonesia.

Kedua, keterikatan publik (civic engagement) sebagai tahapan kedua dari kesadaran politik hadir dalam kasus Cicak versus Buaya pada 20122013 juga menarik untuk dicermati. Aktivisme online kelas menengah yang semula hanya bermuara masalah pelayanan publik, kini sudah merambah pada masalah politik kontemporer. Masalah korupsi dan moralitas menjadi isu penting yang diangkat kelas menengah Indonesia melalui media sosial. Berbagai pesan politik seperti halnya "Gerakan 1 Juta Pendukung KPK" \#SelamatkanKPK, \#KamiCicak, dan lain sebagainya merupakan bentuk ekspresi kelas menengah terhadap kriminalisasi pimpinan KPK tersebut. Dalam benak publik, KPK merupakan satu-satunya lembaga yang masih dipercaya publik sehingga perlu dibela secara serempak. Hasil perjuangan dari gerakan Cicak versus Buaya tersebut berdampak pada tekanan pada Presiden untuk mengambil tindakan terhadap kriminalisasi KPK tersebut.

Ketiga, keterikatan politik (political engagement) dapat dilihat dari munculnya kasus "Relawan" pada pemilu 2014. Melalui tagline \#SalamDuaJari, kelas menengah dapat menampilkan diri sebagai kekuatan politik partisan publik untuk mendukung Jokowi sebagai Presiden selanjutnya. Pemilu 2014 silam merupakan titik krusial bagi suksesi kekuasaan Indonesia dimana terdapat kebutuhan untuk mengakhiri elitisme dan oligarki kekuasaan dengan kebutuhan adanya figur populisme untuk mengakhiri oligarki kekuasaan tersebut. Maka tagline \#SalamDuaJari dipilih publik, selain halnya mewakili afiliasi terhadap Jokowi, namun juga bentuk budaya populer mengajak setiap anggota bermasyarakat lainnya untuk hadir dan berpartisipasi dalam Salam Dua Jari tersebut. Kemenangan Jokowi pada Pemilu 2014 merupakan bentuk kemenangan publik yang didominasi kelas menengah Indonesia.

Dari ketiga pola aktivisme online yang sudah diuraikan tersebut, pola menarik yang bisa dianalisis adalah berkembangnya budaya populer massa dari aktivisme online tersebut. Dalam hal ini, pesan-pesan politik melalui transmisi sosial media tersebut memberikan pengaruh besar terhadap terbentuknya identitas politik kelas menengah tersebut. Hal itulah yang sebenarnya menjadi anomali dalam memahami kelas menengah Indonesia sekarang ini dimana kelas menengah mampu menjadi kekuatan politik tersendiri.

\section{Kesimpulan}

Munculnya sosial media telah memunculkan adanya arena ruang publik baru bagi kelas menengah Indonesia secara keseluruhan. Cyberspace menawarkan adanya deliberasi terhadap nilai-nilai demokrasi baru seperti halnya voluntarisme, egalitarian, maupun juga partisipatorisme. Beberapa nilai demokrasi itulah yang dideliberasikan melalui sosial media tersebut. Aanya proses dialogis yang komunikatif menjadikan kelas menengah Indonesia yang politis terhadap isu-isu politik tertentu. 
Ketiga contoh kasus gerakan yang telah disebutkan di awal adalah bagian dari proses tansformasi ruang publik dalam kasus kelas menengah Indonesia masa kini. Munculnya rasa afeksi, afiliasi, maupun psikologis secara komunal merupakan bagian dari proses mengikat kelas menengah Indonesia secara politis. Meskipun proses pengikatan tersebut juga tidak berlangsung secara simultan dikarenakan adanya perbedaan infrastruktur teknologi yang berbeda antar pulau-pulau di Indonesia.

Tantangan kedepan dalam membahas aktivisme online di Indonesia adalah masih munculnya digital devide maupun juga digital sectionalism yang masih melanda dalam kelas menengah Indonesia. Jawa masih menjadi sentral pembangunan internet, sementara non Jawa hanya menjadi follower bagi perkembangan dunia sosial-politik kelas menengah Jawa. Maka depan, perlu adanya diseminasi terhadap inetrnet perlu dibuka secara meluas di kalangan penduduk kelas menengah Indonesia secara keseluruhan agar kesadaran politik juga terdispersi secara meluas.

\section{Daftar Pustaka}

APJII and Puskakom - UI. (2015). Profil Pengguna Internet Indonesia 2014. Jakarta: APJII Press.

Calhoun, Craig. (eds.) (1992). Habermas and the Public Sphere. London: MIT Press.

Habermas, Jurgen. (2015). The Structural Transformation of the Public Sphere. Cambridge: Polity Press.
McCarthy, Thomas. (1992). Practical Discourse: On The Relation of Morality to Politics. Pp 51-73. Edited Calhoun, Craig. London: MIT Press.

Postill, John. (2012). Digital Politics and Political Engagement. Edited $\mathrm{H}$. Horst and D.Miller. Oxford: Berg

Schuler, Douglas \& Day, Peter. (2004). Shaping the Network Society: The New Role of Civil Society in Cyberspace. London: MIT Press.

Soesono, Nuri. (2013). Representasi Politik: Perkembangan dari Ajektiva ke Teori. Depok: Puskapol - UI.

\section{Sumber Internet}

Jati, Wasisto. (2015). Prospek Politik Digital dalam Kelas Menengah Indonesia. Retrieved from http://www.politik.lipi.go.id/kolo $\mathrm{m} /$ kolom-2/politiknasional/1012-wasisto-raharjojati. Accesed 18 Desember 2015.

KOMPAS. (2013). Lima Korban Pasal Karet UU ITE. Retrieved from http://tekno.kompas.com/read/2 015/01/30/16170037/Lima.Korb an.Pasal.Karet.UU.ITE. Accesed 18 Desember 2015.

Subijanto, Rianne. (2014). Ruang Publik Dulu dan Sekarang. Retrieved from http://indoprogress.com/2014/0 4/ruang-publik-dulu-dansekarang/. Accesed 18 Desember 2015. 